\title{
Audit Committee Characteristics and Carbon Emission Disclosure
}

\author{
Anis Chariri $^{1}$, Indira Januarti, Etna Nur Afri Yuyetta \\ Faculty of Economics and Business \\ Universitas Diponegoro
}

\begin{abstract}
Business activities have contributed to the increasing level of carbon emissions, which can endanger the environment. Such phenomena have pushed companies to disclose a variety of carbon emission information to show their responsibilities. Thus, this study aims to investigate the influence of audit characteristics (independence, expertise, meetings) on carbon emission disclosure. Data were collected from the Nordic companies, which were registered in the 2015 Carbon Disclosure Project. A total of 105 companies were used as samples for further analysis. A regression model was then employed to analyse the data. The findings showed that all characteristics of audit committees (independent audit committee, audit committee expertise and audit committee meetings) positively affected carbon emission disclosure. This study implies that companies that are interested in disclosing carbon emission information should create more independent members of audit committees whose expertise or experiences are in accounting/finance/risk. The audit committee members should be also actively involved in regular meetings to monitor and evaluate company's policy on carbon emission disclosure.
\end{abstract}

Keywords: Independent audit committee; audit committee expertise ; audit committee meetings ; carbon emission disclosure; Nordic

\section{Introduction}

Business activities have been suspected as one contributor of global warming, which affect sustainability issues [1]. Increases in greenhouse gases emitted from fossil fuels such as oil, natural gas and coal are perceived as the main reason for the current climate change [2]. It is important to note that the progress of climate change may be slow and difficult to measure but has a huge impact on business [1]. It is widely known companies produce carbon dioxide, carbon monoxide, and other methane wastes that can damage public health, harm the environment, cause air pollution and increase global warming [3]. This has led to the shift of business orientation from profit (1P) to profit, people and planet (3P) [4].

Companies are now more concerned to the environmental issues by disclosing information about environmental issues including carbon gas emission. Thus, the number of companies voluntarily disclose carbon emission information tend to increase yearly. Carbon emission disclosure provides companies with some advantages such gaining legitimacy and avoiding threats, such as increased operating costs, reduced demand, reputational risk, legal proceedings, and penalties [3]. Unfortunately, this type of disclosure is voluntary and consequently, only companies with specific characteristics may disclose the information. These specific characteristics may be audit committee as audit committee plays important roles in monitoring corporate reporting including disclosure practices. These issues have also attracted accounting scholars to study carbon emission disclosure.

Unfortunately, the previous studies have been directed to investigate the effect of internal audit on GHG reporting [5], how carbon emissions influence corporate value [6], [7], quality disclosure of GHG emission [8], GHG voluntary disclosure, firm size and corporate governance [9], the effect of corporate climate change disclosure on performance [10], and the influence of corporate board's characteristics [11], [12] and corporate governance quality [13] on GHG emission disclosure. The studies have contributed to the current findings on carbon emission disclosure but they ignore the importance of audit committee characteristics. Thus, this study aims to investigate how audit committee characteristics (independent audit committee, audit committee expertise and audit committee meetings) determine carbon emission disclosure.

Findings of this study can be used by companies to consider low carbon emission issues as parts of their business strategies. Secondly, accounting scholars should include carbon emission issues as parts of their research interests and teaching. Finally, the finding of this study can be utilised by regulators as a reference in publishing low carbon business and accounting regulations to support sustainable development.

\footnotetext{
$\overline{{ }^{1} \text { Corresponding author: anis chariri@live.undip.ac.id }}$
} 


\section{Hypothesis Development}

Climate change is widely recognized as the most significant environmental issue facing the global economy. Some consider this to be the greatest challenge for mankind [2]. As part of companies' responsibility for the climate change, companies are motivated to disclose information about carbon emission they produce. Unfortunately, carbon emission disclosure is voluntary. Thus, not all companies disclose information about carbon emission. This implies that unique characteristics of companies may influence the way the companies disclose such information. In this regard, audit committee characteristics are perceived as unique aspects of the companies that differentiate one company to other in disclosing information about carbon emission. Such characteristics include independence, expertise and activities (meetings)

\subsection{Independent Audit Committee and Carbon Emission Disclosure}

Based on the agency theory, agency problems such as information asymmetry and differences of interests between agents and principals can be overcome by the role of the audit committee. It is believed that independent audit committee play important roles in monitoring management especially in disclosing any information of the companies, including information about carbon emission [14]. This is reasonable as independent audit committees have no economic or personal relationship to the management, so they tend to work independently and objectively from the influence of management [15]. Furthermore, independent audit committees have more opportunities to control and reduce management opportunities to retain information for their own benefit [16]. An independent audit committee will ensure the quality and transparency of the financial reporting process, and which in turn reduces information asymmetry [16]. Therefore, effective oversight by an independent audit committee is expected to further motivate management to provide accurate and additional information [17]. In fact, independent audit committees are significantly associated with voluntary disclosure [18], [19], including carbon emission disclosure. Thus, we propose the following hypothesis:

\section{$H_{1}$ : Independent audit committee positively affects carbon emissions disclosure.}

\subsection{Audit Committee Expertise and Carbon Emission Disclosure}

Audit committee expertise plays an important role in supporting audit committee monitor financial reporting prepared by management. Indeed, in order to be effective in monitoring the company reporting process, audit committee members must have financial expertise, so that they can understand and interpret financial statements [20]. Moreover financial expertise provided audit committee members with the ability to oversee management and external audits in producing high quality of financial reporting [15]. This will improve the transparency of corporate reporting and reduce agency issues associated with information flows.

Referring to previous studies, audit committee expertise is positively related to financial reporting quality [21], [22]. In addition, audit committee expertise had a positive effect on the level of voluntary disclosure [18]. These arguments imply that audit committee expertise in accounting and finance plays important roles in affecting the company's decision making in financial reporting, including carbon emission disclosure. Therefore, the next hypothesis is formulated as follow:

$\mathrm{H}_{2}$ : Audit committee expertise positively affects carbon emissions disclosure.

\subsection{Audit Committee Meeting and Carbon Emission Disclosure}

Borrowing agency theory claims, the effectiveness of the audit committee in monitoring management in regard to financial reporting and information disclosure depend on how active the audit committee members are in attending regular meetings. In fact, audit committee members who more frequently attend regular meeting are more effective in their oversight roles [23]. Moreover, the frequency of audit committee meetings will allow members to effectively assess the company's choice on accounting principles, disclosures, and estimates [16]. Furthermore, the more active the audit committee members in regular meetings, the greater their opportunities in discussing and evaluating issues concerning company's financial reporting practices [24][26]. Indeed, audit committee meetings, at least four meetings a year, significantly influenced voluntary disclosure [16], [27]. Based on the arguments, it is believed that the more frequent the audit committee members attend regular meeting, the higher the level of carbon emission disclosure. Thus, we propose the third hypothesis as follow:

$H_{3}$ : Audit Committee meetings have a positive effect
on carbon emissions disclosure.

\section{Research Method}

Dependent variable in this research is carbon emission disclosure (CED). CED is defined as how the company reduce and voluntarily disclose information about the amount of carbon emissions produced by the company. This variable is measured using the carbon emissions disclosure scores obtained from the Nordic Carbon Disclosure Project in 2015. The carbon emissions disclosure score starts from 0 to 100 , where a score of 100 means the company discloses carbon emissions very well.

Independent Variables of this study consist of Independent Audit Committee (IAC), which is measured by calculating the percentage of independent audit committee to total members of audit committee of the company. Secondly, Audit Committee Expertise (ACE) is measured by calculating the number of audit 
committee members with finance/accounting expertise. Thirdly, Audit Committee Meetings (ACM) are measured by counting the number of audit committee meetings for one year.

The population of this study are all companies from Nordics countries (Denmark, Finland, Iceland, Norway, and Sweden), which are registered in the 2015 Carbon Disclosure Projects). Sampling is based on the following criteria: a) Companies are registered on the 2015 Nordic CDP and have numerical scores, b) Companies publish annual reports in 2015, c) Companies have complete data as required for research. The available data are then analysed using the following regression model:

$$
C E D=\alpha+\beta_{1} A C I+\beta_{2} A C E+\beta_{3} A C M+e
$$

\section{Research Findings and Discussion}

This study was conducted with the aim of analysing and investigating the influence of independent audit committees, audit committee expertise and audit committee meetings on carbon emissions disclosure. The description of sample used for this study can be seen from Table 1. It can be seen that based on the availability of data, 174 companies were registered on the 2015 Carbon Disclosure Project. However, only 105 companies meet all criteria of the required sample. In Fact, 18 companies in the CDP list whose annual reports are unavailable on websites, and 23 companies were awarded alphabetical scores (not numerical scores) and 18 companies have incomplete data. The descriptive statistics of empirical data can be seen in Table 2 .

Table 1. Population and Sample

\begin{tabular}{|c|c|}
\hline Criteria & Total \\
\hline Companies registered in the 2015 Nordic CDP & 174 \\
\hline $\begin{array}{c}\text { Companies registered in the 2015 Nordic CDP } \\
\text { but have no published annual reports }\end{array}$ & $(18)$ \\
\hline $\begin{array}{c}\text { Companies registered in the 2015 Nordic CDP } \\
\text { but have no numerical scores }\end{array}$ & $(23)$ \\
\hline Companies with incomplete data as required & $(28)$ \\
\hline Total sample & 105 \\
\hline
\end{tabular}

Table 2 shows the dependent variable (CED) has an average score of 89.07, which means that all Nordic companies have high levels of carbon emission disclosure. Meanwhile, independent audit committee (ACI) have the average value of 80.80 . This implies that most of audit committee of Nordic companies are dominated by independent members. Moreover, Audit committee Expertise (ACE) has an average value of 51.17, which means that at least one of audit committee members have expertise in accounting/finance. Finally, it can be seen that audit committee meeting (ACM) has the average value of 5.0943. This means that the audit committee members meet frequently during one year.
Table 2. Descriptive Statistics

\begin{tabular}{|c|c|c|c|c|c|}
\hline Var & $\mathbf{N}$ & Min & Max & Mean & SD \\
\hline CED & 105 & 28.00 & 100.00 & 89.09 & 16.21 \\
\hline ACI & 105 & 25.00 & 100.00 & 76.16 & 30.90 \\
\hline ACE & 105 & 20.00 & 100.00 & 51.35 & 21.93 \\
\hline ACM & 105 & 1.00 & 10.00 & 5.09 & 2.02 \\
\hline
\end{tabular}

Table 3. Pearson Correlation

\begin{tabular}{|c|c|c|c|c|}
\hline Variables & CED & ACI & ACE & ACM \\
\hline CED & 1.0000 & & & \\
\hline ACI & $0.3267^{*}$ & 1.0000 & & \\
& $(0.0007)$ & & & \\
\hline ACE & $0.1747^{*}$ & -0.0086 & 1.0000 & \\
& $(0.0447)$ & 0.9306 & & \\
\hline ACM & $0.2446^{*}$ & -0.0033 & -0.0133 & 1.0000 \\
& $(0.0119)$ & 0.9731 & 0.8925 & \\
\hline
\end{tabular}

As this study aims to investigate the determinants of carbon emission disclosure, we then examine the available data using a regression model to conclude whether independent audit committee, audit committee expertise and audit committee meeting affect carbon emission disclosure. The result can be seen on Table 3 (Pearson correlation) and Table 4 (Regression Results). It can be seen from Table 3 that all variables have correlation with carbon emission disclosure. Moreover, Table 4 supported all hypotheses that determinant variables consisting of independent audit committee, audit committee expertise and audit committee meeting significantly influenced carbon emission disclosure.

Table 4. Regression Result (Carbon Emission Disclosure $=$ Independent)

\begin{tabular}{|c|c|c|c|c|}
\hline Variable & Coef. & Std. Err. & $\mathbf{t}$ & $\mathbf{P}>|\mathbf{t}|$ \\
\hline ACI & 0.173 & 0.047 & 3.70 & $0.000^{*}$ \\
\hline ACE & 0.133 & 0.066 & 2.03 & $0.045^{*}$ \\
\hline ACM & 1.990 & 0.714 & 2.79 & $0.006^{*}$ \\
\hline Cons & 58.93 & 6.326 & 9.31 & 0.000 \\
\hline $\begin{array}{l}\text { Note: } \\
\text { *Significant at 5\%, N }=105 ; \mathrm{F}(3,101)=8.41, \text { Prob }>\mathrm{F}= \\
0.000, \text { Adj R-Squared }=0.1760\end{array}$ \\
\hline
\end{tabular}

The first hypothesis claims that independent audit committees positively affect carbon emission disclosure. This hypothesis was supported by empirical finding, which means that the more the number of independent audit committees in a company the better the carbon emissions disclosure. The finding support agency theory claiming that independent audit committees play important roles in supervisory duties to effectively monitor agent behaviour. This study is also consistent with previous studies on environmental issues that there is positive relationship of independent audit committee and environmental disclosure, where an increasing number of independent audit committees can encourage the company to make better environmental disclosure [24], [28], [29] 
The second hypothesis claims that audit committee expertise influence carbon emission disclosure. This hypothesis is also supported by empirical evidence. Companies to which the audit committee members have financial or accounting expertise have better carbon emissions disclosure compared to those with fewer financial or accounting expertise. Based on the data it can be seen that members of audit committees in this study mostly has financial and accounting expertise so that it can perform the task of monitoring financial reporting including carbon emission disclosure. The finding of this research is in line with agency theory, that audit committee must have good competence in order to increase its effectiveness so as to prevent the asymmetry of information and interests between agent and principal. Audit committees with finance/accounting expertise are essential requirements for audit committees to perform an effective supervisory role. This study completed the previous studies that audit committee with accounting expertise positively affected voluntary disclosure [25], [27], [30].

The third hypothesis states that audit committee meetings positively influence carbon emission disclosure. The finding showed that the hypothesis was supported by empirical evidence. This means that more frequent meetings of the audit committee members encourage companies to make better carbon emission disclosure. In fact, this study showed that the audit committee members conducted at least 5 time meeting a year. This study supports previous studies that the audit committee meeting should be at least four times a year to make the audit committee effective [31], [32]. To produce good quality oversight, the audit committee needs regular meeting meetings so that in the meeting the audit committee can take responsibility for its functions and supervisory duties to agents and companies. The more often the audit committee meetings, the better the carbon emission disclosure. Indeed, audit committee meetings will encourage high levels of corporate activity such as financial reporting and disclosure [24], [33], [34]

\section{Conclusion and Implication}

This study aims to investigate the influence of independent audit committees, audit committee expertise and audit committee meetings on carbon emissions disclosure of the Nordic companies registered in the 2015 Carbon Disclosure Projects. Based on the empirical findings, we concluded that on average the level of carbon emission disclosure of Nordic countries is high (more than $75 \%$ ). In addition, regression results showed that independent audit committee, audit committee expertise and audit committee meeting positively and significantly affected carbon emission disclosure. The findings are consistent with claims by agency theory. Indeed, independent audit committees make their members more objective and neutral in supervising management in regard to financial reporting practice including carbon emission disclosure. Moreover, the more expert the audit committee members in finance/accounting, the better their ability in reviewing and monitoring the preparation and presentation of carbon emission information. Lastly, the more active the audit committee members in regular meetings, the more effective the members in monitoring management concerning carbon emission disclosure.

The findings imply that to increase the quality and quantity of carbon emission disclosure, the members of audit committees should be independent and expert in finance/accounting as well as regularly hold meetings (at least four times a year). Secondly, the findings can be used by regulators especially financial service authorities as a reference to review the role of audit committee in financial reporting especially carbon emission disclosure.

Regardless the important findings, this study suffers from weaknesses. Firstly, the findings are relevant to the Nordic companies but may not be generalized for companies in other countries. Secondly, this study only considered audit committee characteristics. Thus, other variables may also determine carbon emission disclosure. It is important to note that the future studies should consider companies from other countries to enhance the findings. Lastly, the next research may include board of commissioners, environmental management certification, external auditors, or environment committee.

\section{References}

1 J. T. D. Ratnatunga and K. R. Balachandran, "Carbon Business Accounting: The Impact of Global Warming on the Cost and Management Accounting Profession," $J$. Accounting, Audit. Financ., vol. 24, no. 2, pp. 333-355, 2009.

2 R. Henderson, S. Reinert, P. Dekhtyar, and A. Migdal, "Climate Change in 2016: Implications for Business," Harvard Bus. Sch., no. May, 2016.

3 S. Berthelot and A.-M. Robert, "Climate change disclosures: An examination of Canadian oil and gas firms," Issues Soc. Environ. Account., vol. 5, no. 12, pp. 106-123, 2011.

4 J. Elkington, Cannibals with forks the triple bottom line of 21st century business. Oxford: Capstone Publishing Ltd, 1997.

5 A. J. . Trotman and K. T. . Trotman, "Internal audit's role in GHG emissions and energy reporting: Evidence from audit committees, senior accountants, and internal auditors," Auditing, vol. 34, no. 1, pp. 199-230, 2015.

6 R. Aggarwal and S. Dow, "Greenhouse Gas Emissions Mitigation and Firm Value: A Study of Large NorthAmerican and European Firms," Midwest Financ. Assoc. 2012 Annu. Meet. Electron. J., no. September 2011, p. 38, 2011.

7 E. M. Matsumura, R. Prakash, and S. C. Vera-Muñoz, "Firm-value effects of carbon emissions and carbon disclosures," Account. Rev., vol. 89, no. 2, pp. 695-724, 2014.

8 J. L. Hollindale, "Voluntary disclosure of GHG emission information by Australian Companies," Phd Thesis, no. June, 2012.

9 Z. Borghei-Ghomi and P. Leung, "An Empirical Analysis of the Determinants of Greenhouse Gas Voluntary Disclosure in Australia," Account. Financ. Res., vol. 2, no. 1, pp. 110-127, 2013.

10 A. Liesen, F. Figge, A. Hoepner, and D. M. Patten, 
"Climate Change and Asset Prices: Are Corporate Carbon Disclosure and Performance Priced Appropriately?," J. Bus. Financ. Account., vol. 44, no. 1-2, pp. 35-62, 2016.

11 L. Liao, L. Luo, and Q. Tang, "Gender diversity, board independence, environmental committee and greenhouse gas disclosure," Br. Account. Rev., vol. 47, no. 4, pp. 409-424, Feb. 2015.

12 F. Haque, "The effects of board characteristics and sustainable compensation policy on carbon performance of UK firms," Br. Account. Rev., vol. 49, no. 3, pp. 347364, 2017.

13 M. Rankin, C. Windsor, and D. Wahyuni, "An investigation of voluntary corporate greenhouse gas emissions reporting in a market governance system," Accounting, Audit. Account. J., vol. 24, no. 8, pp. $1037-$ 1070, Oct. 2011.

14 M. C. Jensen and W. H. Meckling, "Theory of the firm: Managerial behavior, agency costs and ownership structure," J. financ. econ., vol. 3, no. 4, pp. 305-360, 1976.

15 J. Bédard and Y. Gendron, "Strengthening the Financial Reporting System: Can Audit Committees Deliver?," Int. J. Audit., vol. 14, no. 2, pp. 174-210, 2010.

16 M. Allegrini and G. Greco, "Corporate boards, audit committees and voluntary disclosure: evidence from Italian Listed Companies," J. Manag. Gov., vol. 17, no. 1, pp. 187-216, 2013.

17 R. Haniffa and T. . Cooke, "Culture, Corporate Governance and Disclosure in Malaysian Corporations," Abacus, vol. 38, no. 3, pp. 317-439, 2002.

18 M. Akhtaruddin and H. Haron, "Board ownership, audit committees' effectiveness and corporate voluntary disclosures," Asian Rev. Account., vol. 18, no. 1, pp. 6882, 2010.

19 L. Patelli and A. Prencipe, "The Relationship between Voluntary Disclosure and Independent Directors in the Presence of a Dominant Shareholder," Eur. Account. Rev., vol. 16, no. 1, pp. 5-33, 2007.

20 D. A. N. Dhaliwal, V. I. C. Naiker, and F. Navissi, "The Association Between Accruals Quality and the Characteristics of Accounting Experts and Mix of Expertise on Audit Committees*," Contemp. Account. Res., vol. 27, no. 3, pp. 787-827, 2010.

21 A. S. Kelton and Y. Yang, "The impact of corporate governance on Internet financial reporting," J. Account. Public Policy, vol. 27, no. 1, pp. 62-87, 2008.

22 P. Kent, J. Routledge, and J. Stewart, "Innate and discretionary accruals quality and corporate governance," Account. Financ., vol. 50, no. 1, pp. 171195,2010
23 I. Karamanou and N. Vafeas, "The Association between Corporate Boards, Audit Committees, and Management Earnings Forecasts: An Empirical Analysis," J. Account. Res., vol. 43, no. 3, pp. 453-486, 2005.

24 A. Chariri and I. Januarti, "Audit Committee Characteristics and Integrated Reporting: Empirical Study of Companies Listed on the Johannesburg Stock Exchange," Eur. Res. Stud. J., vol. XX, no. 4, pp. 305318,2017

25 S. Hundal, "Independence, Expertise and Experience of Audit Committees: Some Aspects of Indian Corporate Sector," Am. Int. J. Soc. Sci., vol. 2, no. 5, pp. 58-75, 2013.

26 N. Vafeas, "Audit Committees, Boards, and the Quality of Reported Earnings*," Contemp. Account. Res., vol. 22, no. 4, pp. 1093-1122, 2005.

27 J. Li, M. Mangena, and R. Pike, "The effect of audit committee characteristics on intellectual capital disclosure," Br. Account. Rev., vol. 44, no. 2, pp. 98110, 2012.

28 L. Spira, "An Evolutionary Perspective on Audit Committee Effectiveness," Corp. Gov. An Int. Rev., vol. 6, no. 1, pp. 29-38, 1998.

29 S. N. Bronson, J. V Carcello, C. W. Hollingsworth, and T. L. Neal, "Are fully independent audit committees really necessary?," J. Account. Public Policy, vol. 28, no. 4, pp. 265-280, 2009.

30 J. L. . Abernathy, A. . Masli, and C. M. . Stefaniak, "How the source of audit committee accounting expertise influences financial reporting timeliness," Curr. Issues Audit., vol. 9, no. 1, pp. P1--P9, 2015.

31 D. N. Hurtt, J. G. Kreuze, and S. A. Langsam, "Blue ribbon panel reports: How you must improve your audit committee," J. Corp. Account. Financ., vol. 11, no. 1, pp. 115-125, 1999.

32 A. J. Felo, S. Krishnamurthy, and S. A. Solieri, "Audit Committee Characteristics and the Perceived Quality of Financial Reporting: An Empirical Analysis," Available SSRN, vol. April, 2003.

33 L. Kalbers and T. J. Fogarty, "Audit Committee Effectiveness: An Empirical Investigation of the Contribution of Power," Audit. A J. Pract. Theory, vol. 12, pp. 24-49, 1993.

34 A. Ahmed Haji, "The role of audit committee attributes in intellectual capital disclosures: Evidence from Malaysia," Manag. Audit. J., vol. 30, no. 8-9, pp. 756784, 2015 